\title{
LETTER
}

\section{Checklist for percutaneous tracheostomy in critical care}

\author{
Gokulnath Rajendran ${ }^{*}$ and Stephen Hutchinson \\ See related research by Simon et al., http://ccforum.com/content/17/5/R258
}

Simon and colleagues are to be commended for their effort in reviewing articles published since 1985 on the incidence and risk factors associated with mortality following percutaneous dilatational tracheostomy (PDT) [1].

An important milestone in an attempt to reduce surgery-related complications was the introduction of the World Health Organization Surgical Safety Checklist in 2008. A pilot study showed a reduction in both mortality and potential complications following introduction of the checklist [2]. Over 300 organisations have endorsed the campaign worldwide and 1,790 hospitals are actively using the checklist with more than 4,100 hospitals registered [3].

With such broad recognition of the importance for safety and implementation of the checklist in general surgery, it seems appropriate to follow a similar checklist for the PDT procedure in intensive care. Checklists are not alien to ICUs. Checklists have helped nursing staff to adhere to infection control guidelines and hence a reduction in bloodstream-related infections [4]. Several other checklists (mechanical ventilation, daily goals [5]) have proven useful.

The checklist before PDT (see Table 1) is intended to reduce error and harm. Although the clinician has overall responsibility for ensuring that it is safe to undergo PDT, having a checklist would also provide an opportunity for the nurses to highlight or challenge any criteria that are not followed. We believe that if the checklist is tailor-made to suit individual organisations, it does not overstrain clinicians and may actually improve safety and efficiency.

\footnotetext{
* Correspondence: drgokul100@gmail.com

Norfolk and Norwich University Hospitals, Colney Lane, Norwich NR4 7UY, UK
}

Table 1 Proposed checklist before percutaneous dilatational tracheostomy (pre and post)

Preparation

Confirm patient's consent or next of kin's assent

Is the neck anatomy favourable (no previous surgery or radiotherapy?)

Ultrasound of the neck performed? (Midline/abnormal vessels absent?)

$\mathrm{FiO}_{2}$ requirement $<70 \%$, PEEP $<10 \mathrm{~mm} \mathrm{Hg}$

Is coagulation okay? (Platelets $>80,000 / \mu$, INR $<1.5$, APTT

$<45$ seconds)

Anticoagulants and antiplatelets withheld?

Gastric feeding suspended?

\section{Procedure}

Airway management and anaesthesia: $\mathrm{Dr}$

Tracheostomy: Dr.

Minimum monitoring $\left(\mathrm{ECG} / \mathrm{SpO}_{2} / \mathrm{NIBP} / \mathrm{EtCO} \mathrm{CO}_{2}\right)$

Airway rescue equipment available?

General anaesthesia (propofol + opioid) and paralysis (atracurium)

$20 \mathrm{ml}$ local anaesthesia - 1 \% lignocaine with adrenaline

Ciaglia dilatational tracheostomy (preferably with subglottic suction). A range of tube sizes and adjustable flange tube should be available

Airway toilet/suction and bronchoscopy

Tracheostomy position is confirmed by $\mathrm{EtCO}_{2}$ and bronchoscopy

Tracheostomy is secured with sutures and tapes, and inner cannula inserted

\section{Post procedure}

Check chest X-ray satisfactory?

Document in the clinical record

Review sedation and ventilation

APTT, activated partial pressure thromboplastin time; $\mathrm{ECG}$, electrocardiogram; $\mathrm{EtCO}_{2}$ level of carbon dioxide released at the end of expiration; $\mathrm{FiO}_{2}$, fraction of inspired oxygen; INR, international normalised ratio; NIBP, non-invasive blood pressure; PEEP, positive end-expiratory pressure; $\mathrm{SpO}_{2}$, blood oxygen saturation. 


\section{Abbreviation}

PDT: Percutaneous dilatational tracheostomy.

\section{Competing interests}

The authors declare that they have no competing interests.

\section{Published: 16 Apr 2014}

\section{References}

1. Simon M, Metschke M, Braune SA, Püschel K, Kluge S: Death after percutaneous dilatational tracheostomy: a systematic review and analysis of risk factors. Crit Care 2013, 17:R258.

2. Haynes AB, Weiser TG, Berry WR, Lipsitz SR, Breizat AH, Dellinger EP, Herbosa T, Joseph S, Kibatala PL, Lapitan MC, Merry AF, Moorthy K, Reznick RK, Taylor B, Gawande AA, Safe Surgery Saves Lives Study Group: A surgical safety checklist to reduce morbidity and mortality in a global population. $N$ Engl J Med 2009, 360:491-499.

3. Surgical Safety Web Map. http://maps.cga.harvard.edu:8080/Hospital/.

4. Pronovost $P$, Needham D, Berenholtz $S$, Sinopoli D, Chu H, Cosgrove $S$, Sexton B, Hyzy R, Welsh R, Roth G, Bander J, Kepros J, Goeschel C: An intervention to decrease catheter-related bloodstream infections in the ICU. N Engl J Med 2006, 355:2725-2732.

5. Pronovost $P$, Berenholtz S, Dorman T, Lipsett PA, Simmonds T, Haraden C: Improving communication in the ICU using daily goals. J Crit Care 2003, 18:71-75.

$10.1186 / \mathrm{cc} 13833$

Cite this article as: Rajendran and Hutchinson: Checklist for percutaneous tracheostomy in critical care. Critical Care 2014, 18:425 